The University of San Francisco

USF Scholarship: a digital repository@Gleeson Library | Geschke Center

2001

\title{
Thermodynamic Investigation of the Si7 and Si8 Clusters by Knudsen Cell Mass Spectrometry
}

Giovanni Meloni

University of San Francisco, gmeloni@usfca.edu

Karl A. Gingerich

Follow this and additional works at: http://repository.usfca.edu/chem_fac

Part of the Chemistry Commons

\section{Recommended Citation}

Meloni, G., Gingerich, K. A. Thermodynamic investigation of the Si[sub 7] and Si[sub 8] clusters by Knudsen cell mass spectrometry. Journal of Chemical Physics. 9/22/2001, Vol. 115 Issue 12.

This Article is brought to you for free and open access by the Chemistry at USF Scholarship: a digital repository @ Gleeson Library| Geschke Center. It has been accepted for inclusion in Chemistry Faculty Publications by an authorized administrator of USF Scholarship: a digital repository @ Gleeson Library | Geschke Center. For more information, please contact repository@usfca.edu. 


\title{
Thermodynamic investigation of the $\mathrm{Si}_{7}$ and $\mathrm{Si}_{8}$ clusters by Knudsen cell mass spectrometry
}

\author{
G. Meloni ${ }^{\mathrm{a}}$ and K. A. Gingerich ${ }^{\mathrm{b})}$ \\ Department of Chemistry, Texas A\&M University, P.O. Box 30012, College Station, Texas 77842-3012
}

(Received 3 April 2001; accepted 18 June 2001)

\begin{abstract}
The Knudsen cell mass spectrometric method has been employed to measure the partial pressures of the $\mathrm{Si}_{7}$ and $\mathrm{Si}_{8}$ clusters under equilibrium conditions above liquid silicon, contained in a boron nitride liner inside a graphite Knudsen cell. Gaussian 2 (G2) theory and B3LYP density functional method were employed to determine the geometry, the vibrational frequencies, and the binding energy of the $\mathrm{Si}_{8}$ cluster. From the all-gas analyzed equilibria the following atomization enthalpies, $\Delta_{a} H_{0}^{\mathrm{o}}\left(\mathrm{Si}_{n}\right)$, and enthalpies of formation, $\Delta_{f} H_{298.15}^{\mathrm{o}}\left(\mathrm{Si}_{n}\right)$, in $\mathrm{kJ} \mathrm{mol}{ }^{-1}$, have been obtained: $\mathrm{Si}_{7}$, $2381 \pm 36$ and $743 \pm 36 ; \mathrm{Si}_{8}, 2735 \pm 65$ and $837 \pm 65$. Experimental literature values for the electron affinities of $\operatorname{Si}_{n}(n=3-8)$ have been combined with present and previous results to obtain the bonding energies for the $\mathrm{Si}_{n}^{-}(n=3-8)$ cluster anions. The experimental atomization energies are compared with available theoretical values. (c) 2001 American Institute of Physics.
\end{abstract}

[DOI: 10.1063/1.1391265]

\section{INTRODUCTION}

Investigations of the structures, energetics, and reactivities of atomic clusters have attracted a significant interest in recent years. Occupying the intermediate position between the separate atoms and condensed matter, atomic clusters have been studied to develop new approaches in catalysis and in thin film technology, and to explain phenomena such as nucleation processes ${ }^{1}$ and crystal growth at the molecular level. Furthermore the deposition of size-selected atomic clusters on surfaces is of special interest, justified by the belief that it may be possible to preserve, and thus investigate, some of the peculiar size-dependent properties of the corresponding free clusters., ${ }^{2,3}$

Silicon has dominated the semiconductor industry for a long time thanks to its superior electric properties. More recently, silicon is also becoming an interesting material for photonic applications ${ }^{4}$ as a consequence of its photoluminescence and electroluminescence properties. ${ }^{5,6}$ In fact, low dimensional silicon structures show quantum size effects which can greatly alter the properties of the bulk giving rise to a new generation of electronic devices.

The first mass spectrometric observation of silicon clusters has been by Honig, ${ }^{8}$ who measured the ion currents for $\mathrm{Si}^{+}$through $\mathrm{Si}_{7}^{+}$above silicon contained in an open beryllia crucible at temperatures of 1400-1660 K. Silicon clusters and cluster ions have been extensively studied since the $1980 \mathrm{~s}^{9-11}$ when new cluster production techniques started to be employed. A considerable effort has been devoted to the determination of the structures of silicon clusters and the largest cluster with experimentally confirmed geometry is $\mathrm{Si}_{7}$, a pentagonal bipyramid with a $D_{5 h}$ symmetry. ${ }^{12-16}$

Small silicon clusters have been investigated employing several theoretical approaches, such as quantum chemistry methods, ${ }^{17-25}$ tight-binding methods, ${ }^{26-33}$ calculations based

\footnotetext{
a)Electronic mail: meloni@mail.chem.tamu.edu

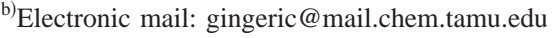

on molecular dynamics methods, ${ }^{34-43}$ on space-fixed genetic algorithms, ${ }^{44,45}$ on interatomic potential functionals, ${ }^{46}$ on orbital-free kinetic-energy functionals, ${ }^{47}$ and on variational fixed-node diffusion Monte Carlo methods. ${ }^{48}$

Many experimental techniques have been employed to study the properties of silicon clusters. ${ }^{12-16,49-55}$ Honea et $a l .{ }^{12,16}$ reported the structures of size-selected silicon clusters using surface-plasmon-polariton (SPP) enhanced Raman spectroscopy. Jarrold and co-workers ${ }^{49,50}$ measured the mobilities of size-selected silicon clusters ions, produced by pulsed laser vaporization of a silicon rod, for their structural characterization. Trevor et al. ${ }^{51}$ and Fuke et al. ${ }^{52}$ examined the photoionization thresholds of silicon clusters by laser photoionization with detection by a time-of-flight mass spectrometer. Cheshnovsky et al. ${ }^{53}$ measured anion ultraviolet photoelectron spectra (UPS) of $\mathrm{Si}_{n}^{-}(n \leqslant 12)$ clusters, yielding electron affinities estimates and a qualitative description of the HOMO-LUMO gap. Neumark and co-workers ${ }^{15,54}$ measured photelectron spectra of $\mathrm{Si}_{n}^{-}(n=3-7)$ clusters at several photodetachment energies, obtaining electronic states, accurate electron affinities, term energies, and vibrational frequencies for the ground state and for excited electronic states of neutral clusters. Bachels and Schäfer ${ }^{55}$ used a pyroelectric calorimeter in combination with a molecular beam apparatus to investigate the binding energies of isolated neutral silicon clusters.

Knudsen-effusion mass spectrometric measurements have been performed by Chatillon ${ }^{56}$ who evaporated a mixture of silicon and $\mathrm{SiC}(s)$ from a glassy graphite cell that was inserted into a tantalum Knudsen cell. He reported second-law enthalpies of formation for $\mathrm{Si}_{2}-\mathrm{Si}_{7}$ at the corresponding average temperatures of measurement. Rocabois et $a .^{57}$ used a multiple Knudsen cell device in which four graphite cells are located in the same tantalum block. One of the cells contained the gold used as standard for pressure calibration; the sample of silicon and $\mathrm{SiC}(s)$ was evaporated 
from another cell. They reported standard enthalpies of formation, $\Delta_{f} H_{298.15}^{\mathrm{o}}$, for $\mathrm{Si}_{2}-\mathrm{Si}_{6}$.

The present investigation of the $\mathrm{Si}_{7}$ and $\mathrm{Si}_{8}$ clusters is an extension of our previous studies of small silicon clusters, $\mathrm{Si}_{2}$ and $\mathrm{Si}_{3},{ }^{58} \mathrm{Si}_{4},{ }^{59} \mathrm{Si}_{5},{ }^{60}$ and $\mathrm{Si}_{6},{ }^{61}$ and a continuation of our systematic study of thermodynamic properties of small atomic clusters of group 14 elements (Refs. 62-65) by Knudsen cell mass spectrometry. We report our results derived form the mass spectrometric equilibrium data for the atomization enthalpies and enthalpies of formation of $\mathrm{Si}_{7}$ and $\mathrm{Si}_{8}$. New thermal functions were calculated from molecular parameters taken from literature for $\mathrm{Si}_{7}$, or calculated by the Gaussian 2 (G2) theoretical procedure for $\mathrm{Si}_{8}$. Preliminary experimental results from our laboratory have been reported in Ref. 66. The atomization energies of $\mathrm{Si}_{7}$ and $\mathrm{Si}_{8}$ obtained in this investigation are compared to predicted values from theoretical approaches. They have also been used, together with the experimental values for the electron affinities by $\mathrm{Xu}$ et al. ${ }^{15}$ for $\mathrm{Si}_{n}(n=3-5,7)$ and by Kishi et al. ${ }^{67}$ for $\mathrm{Si}_{6}$ and $\mathrm{Si}_{8}$, to derive the atomization energies of the corresponding cluster anions.

\section{THEORETICAL INVESTIGATIONS}

The Gaussian 2 (G2) theoretical procedure together with the density functional (DF) method using the Becke threeparameter exchange functional with the Lee, Yang, and Parr correlation functional (B3LYP) were employed to obtain information of the molecular parameters and binding energy of the $\mathrm{Si}_{8}$ cluster. These calculations were carried out utilizing the GAUSSIAN 98 program package. ${ }^{68}$ We employed the G2 method to obtain a reliable atomization enthalpy for $\mathrm{Si}_{8}$. Raghavachari and Curtiss ${ }^{69}$ have compared experimental values for the atomization energies of small carbon clusters and silicon clusters, obtained in our laboratory, with their G2 values, and have shown good agreement within the error limits of the experimental values.

The G2 theory is the combination of several component calculations. Equilibrium geometries are optimized at the second-order Møller-Plesset perturbation theory (MP2) using the 6-31G $(d)$ basis set with all electrons included, and single-point energies are calculated at the second- and fourth-order Møller-Plesset perturbation theory (MP4) and quadratic configuration interaction [QCISD(T)] levels of theory, using the 6-311G $(d, p)$ and 6-311+ $\mathrm{G}(d, p)$ basis sets. Harmonic vibrational frequency and the associated zero-point vibrational energies (ZPVE) are calculated at the Hartree-Fock (HF) level. ZPVE and harmonic vibrational frequencies are scaled by 0.893 . A double-zeta basis set with a diffuse and polarization function $\left(6-31+\mathrm{G}^{*}\right)$ was employed for the B3LYP computations.

At both levels of calculations the ground state of $\mathrm{Si}_{8}$ has a $C_{2 h}{ }^{1} A_{g}$ bicapped octahedral structure. This result agrees with previous computations. ${ }^{19,23,28,29,31,37,39,46}$ Figure 1 shows the $\mathrm{Si}_{8}$ optimized $C_{2 h}$ geometry. The optimized bond lengths and vibrational frequencies, together with the zero point energy (ZPE), computed in this investigation are reported in Table I. The bond lengths calculated at the MP2/6-31G* and the B3LYP/6-31+ $\mathrm{G}^{*}$ levels of theory are almost the same.

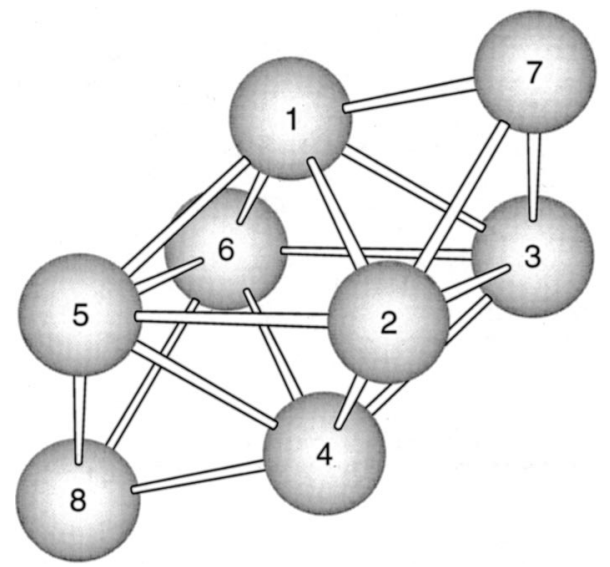

FIG. 1. Ground state geometry of the $\mathrm{Si}_{8}$ cluster as calculated at the $\mathrm{B} 3 \mathrm{LYP} / 6-31+\mathrm{G}^{*}$ and MP2/6-31G* levels of theory.

The two lowest $a_{u}$ and $a_{g}$ normal vibrational modes calculated at the B3LYP/6-31+ $\mathrm{G}^{*}$ level of theory differ substantially from those calculated by the HF/6-31G* level of theory, but the corresponding zero point energies agree within $1 \mathrm{~kJ} \mathrm{~mol}^{-1}$. The $\mathrm{HF} / 6-31 \mathrm{G}^{*}$ vibrational frequencies computed here are the same as those reported by Raghavachari and Rohlfing. ${ }^{19}$ The binding energy of the $\mathrm{Si}_{8}$ cluster was calculated at the B3LYP/6-31+G*, G2(MP2), and G2 levels of theory and the results are reported in Table II. There is good agreement between the G2(MP2) and G2 values, whereas the $\mathrm{B} 3 \mathrm{LYP} / 6-31+\mathrm{G}^{*}$ atomization value is about $300 \mathrm{~kJ} \mathrm{~mol}^{-1}$ smaller than the $\mathrm{G} 2$ value. This is due to the underestimation of the binding energy for this functional.

\section{EXPERIMENT}

The measurements of the partial pressures of the $\mathrm{Si}_{7}$ and $\mathrm{Si}_{8}$ clusters under equilibrium conditions were performed with a Nuclide Corporation 12-90 HT single focusing magnetic deflection type mass spectrometer. Details of the instrument and experimental procedure have been described elsewhere. ${ }^{70}$ Semiconductor grade silicon powder and a small amount of silver wire were contained into a boron nitride $(\mathrm{BN})$ liner, that was placed inside a graphite Knudsen cell.

The measurements were performed in two subsequent parts, series 1 and 2, under different focusing and alignment conditions. The energy of the ionizing electrons was $18 \mathrm{eV}$ for series 1 , and 18 and $13 \mathrm{eV}$ for series 2. The last measurement of series 1 at $1993 \mathrm{~K}$ was carried out with $11 \mathrm{eV}$. The filament emission current was $1 \mathrm{~mA}$, and the accelerating potential was $4.5 \mathrm{kV}$. The ionic species $\mathrm{Si}^{+}, \mathrm{Si}_{7}^{+}$, and $\mathrm{Si}_{8}^{+}$ were identified by their mass-to-charge ratios and isotopic abundance. At each measurement a movable slit was interposed into the molecular beam to distinguish between ions produced from species in the beam and from residual gases with the same mass-to-charge ratio in the ionization region of the mass spectrometer. The ion currents of $\mathrm{Si}_{7}^{+}$and $\mathrm{Si}_{8}^{+}$ were too small for obtaining the respective ionization energies. Table III lists the measured ion currents of the most abundant isotope of the species pertinent to this investigation. Each measurement at $18 \mathrm{eV}$ of the ion intensity of $\mathrm{Si}^{+}$ 
TABLE I. Optimized geometries (bond lengths in $\AA$ ), vibrational frequencies (in $\mathrm{cm}^{-1}$ ), and zero-point energies (in $\mathrm{kJ} \mathrm{mol}^{-1}$ ) for the $\mathrm{Si}_{8} \mathrm{cluster}$ computed at the B3LYP/6-31+G*, HF/6-31G*, and MP2/6-31G* levels of theory.

\begin{tabular}{|c|c|c|c|c|c|c|c|c|c|c|}
\hline \multirow[b]{2}{*}{ Species } & \multirow[b]{2}{*}{ Symmetry } & \multirow{2}{*}{$\begin{array}{l}\text { Electronic } \\
\text { state }\end{array}$} & \multirow[b]{2}{*}{ Bond lengths } & \multirow[b]{2}{*}{ B3LYP } & \multirow[b]{2}{*}{ MP2 } & \multirow{2}{*}{$\begin{array}{l}\text { Vibrational } \\
\text { frequencies }\end{array}$} & \multirow[b]{2}{*}{ B3LYP } & \multirow[b]{2}{*}{$\mathrm{HF}$} & \multicolumn{2}{|c|}{ Zero-point energies } \\
\hline & & & & & & & & & B3LYP & $\mathrm{HF}$ \\
\hline \multirow[t]{18}{*}{$\mathrm{Si}_{8}$} & $C_{2 h}$ & ${ }^{1} A_{g}$ & $\mathrm{Si}_{1}-\mathrm{Si}_{2}$ & 2.523 & 2.455 & $b_{u}$ & 142 & 105 & 29.5 & $28.8^{\mathrm{a}}$ \\
\hline & & & $\mathrm{Si}_{1}-\mathrm{Si}_{3}$ & 2.523 & 2.455 & $a_{u}$ & 64 & 129 & & \\
\hline & & & $\mathrm{Si}_{1}-\mathrm{Si}_{5}$ & 2.431 & 2.391 & $a_{g}$ & 56 & 131 & & \\
\hline & & & $\mathrm{Si}_{1}-\mathrm{Si}_{6}$ & 2.431 & 2.391 & $a_{u}^{s}$ & 156 & 161 & & \\
\hline & & & $\mathrm{Si}_{1}-\mathrm{Si}_{7}$ & 2.274 & 2.271 & $b_{u}$ & 224 & 189 & & \\
\hline & & & $\mathrm{Si}_{2}-\mathrm{Si}_{3}$ & 2.950 & 2.854 & $a_{g}$ & 220 & 196 & & \\
\hline & & & $\mathrm{Si}_{2}-\mathrm{Si}_{4}$ & 2.431 & 2.391 & $b_{g}^{g}$ & 247 & 242 & & \\
\hline & & & $\mathrm{Si}_{2}-\mathrm{Si}_{5}$ & 2.750 & 2.759 & $b_{g}^{g}$ & 292 & 254 & & \\
\hline & & & $\mathrm{Si}_{2}-\mathrm{Si}_{7}$ & 2.497 & 2.447 & $a_{g}$ & 290 & 264 & & \\
\hline & & & $\mathrm{Si}_{3}-\mathrm{Si}_{4}$ & 2.431 & 2.391 & $b_{u}$ & 278 & 265 & & \\
\hline & & & $\mathrm{Si}_{3}-\mathrm{Si}_{6}$ & 2.750 & 2.759 & $b_{g}$ & 315 & 296 & & \\
\hline & & & $\mathrm{Si}_{3}-\mathrm{Si}_{7}$ & 2.497 & 2.447 & $b_{u}^{g}$ & 338 & 296 & & \\
\hline & & & $\mathrm{Si}_{4}-\mathrm{Si}_{5}$ & 2.523 & 2.455 & $a_{g}$ & 299 & 300 & & \\
\hline & & & $\mathrm{Si}_{4}-\mathrm{Si}_{6}$ & 2.523 & 2.455 & $a_{u}$ & 274 & 303 & & \\
\hline & & & $\mathrm{Si}_{4}-\mathrm{Si}_{8}$ & 2.274 & 2.272 & $a_{u}$ & 365 & 342 & & \\
\hline & & & $\mathrm{Si}_{5}-\mathrm{Si}_{6}$ & 2.950 & 2.854 & $a_{g}$ & 368 & 357 & & \\
\hline & & & $\mathrm{Si}_{5}-\mathrm{Si}_{8}$ & 2.497 & 2.447 & $b_{u}^{\delta}$ & 506 & 484 & & \\
\hline & & & $\mathrm{Si}_{6}-\mathrm{Si}_{8}$ & 2.497 & 2.447 & $a_{g}$ & 506 & 489 & & \\
\hline
\end{tabular}

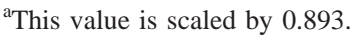

has been corrected for a contribution due to $\mathrm{N}_{2}$ coming from the BN liner. The correction has been done by using the measured ion current of ${ }^{29} \mathrm{Si}^{+}$and ${ }^{29} \mathrm{~N}_{2}^{+}$and their known isotopic abundances. An example is given from the measurement at $1985 \mathrm{~K}$ where the ratio of ${ }^{28} \mathrm{~N}_{2}^{+}$to ${ }^{28} \mathrm{Si}^{+}$is 5.01 using $18 \mathrm{eV}$.

The pressure constant for $\mathrm{Si}, k(\mathrm{Si})$, was determined by comparing the corrected ion intensities of $\mathrm{Si}^{+}$to the equilibrium partial pressure of $\mathrm{Si}$ (Ref. 71) over condensed silicon. The relationship employed is $k(\mathrm{Si})=p(\mathrm{Si}) /\left[I\left(\mathrm{Si}^{+}\right) T\right]$. The pressure calibration constants for $\mathrm{Si}_{7}$ and $\mathrm{Si}_{8}$ were then evaluated from $k\left(\mathrm{Si}_{n}\right)=k(\mathrm{Si}) \sigma(\mathrm{Si}) n(\mathrm{Si}) \gamma(\mathrm{Si})$ $/\left[\sigma\left(\mathrm{Si}_{n}\right) n\left(\mathrm{Si}_{n}\right) \gamma\left(\mathrm{Si}_{n}\right)\right]$, where $\sigma, n$, and $\gamma$ are the ionization cross section, isotopic abundance, and multiplier gain, respectively. The value of $\gamma\left(\mathrm{Si}_{n}\right)$ was assumed to be equal to that of $\gamma(\mathrm{Si})$, implying cancellation of the mass and molecular effects. The ionization cross sections of $\mathrm{Si}_{7}$ and $\mathrm{Si}_{8}$ were calculated assuming $\sigma\left(\mathrm{Si}_{n}\right)=0.75 \times n \times \sigma(\mathrm{Si})$. For series 1 the resulting pressure constants, in bar $\mathrm{A}^{-1} \mathrm{~K}^{-1}$, are at $18 \mathrm{eV}$, 5.42, 1.68, and 1.59, for $\mathrm{Si}, \mathrm{Si}_{7}$, and $\mathrm{Si}_{8}$, respectively; at 11 $\mathrm{eV}, 146.2$ and 45.3 for $\mathrm{Si}_{\text {and }} \mathrm{Si}_{7}$. For series 2 the resulting pressure constants, in bar $\mathrm{A}^{-1} \mathrm{~K}^{-1}$, are for $\mathrm{Si}, \mathrm{Si}_{7}$, and $\mathrm{Si}_{8}$ : at $18 \mathrm{eV}, 29.1,9.02$, and 8.56; at $13 \mathrm{eV}, 66.9,20.7$, and 19.7, respectively. The uncertainty of $k$ is estimated to be about $30 \%$.

\section{RESULTS AND DISCUSSION}

\section{A. Thermal functions}

The Gibbs energy functions, $\left(G_{T}^{\mathrm{o}}-H_{0}^{\mathrm{o}}\right) / T\left(\mathrm{GEF}_{0}\right)$, and the heat content functions, $\left(H_{T}^{\mathrm{o}}-H_{0}^{\mathrm{o}}\right)\left(\mathrm{HCF}_{0}\right)$, needed in the evaluation of the reaction enthalpies were taken from literature for $\mathrm{Si}^{71}$ Those for $\mathrm{Si}_{7}$ and $\mathrm{Si}_{8}$ were calculated according to statistical thermodynamic procedures, using the harmonic oscillator-rigid rotator approximation, ${ }^{72}$ and experimental and/or theoretical molecular parameters.

The $\mathrm{Si}_{7}$ ground state, ${ }^{1} A_{1}^{\prime}$, is a pentagonal bipyramid $\left(D_{5 h}\right)$ with the equatorial lengths equal to $2.48 \AA(\times 5)$, and the equatorial-axial lengths equal to $2.47 \AA(\times 10)$. This structure has a very compressed geometry with the apex atoms being only $2.51 \AA$ apart from each other. ${ }^{16}$ The vibrational frequencies, in $\mathrm{cm}^{-1}$, used in this evaluation are: 188 $(\times 2)\left(e_{2}^{\prime \prime}\right),{ }^{73} 221(\times 2)\left(e_{1}^{\prime}\right),{ }^{13} 249\left(a_{2}^{\prime \prime}\right),{ }^{13} 289(\times 2)\left(e_{2}^{\prime}\right),{ }^{16}$ $340(\times 2)\left(e_{1}^{\prime \prime}\right),{ }^{16} 340(\times 2)\left(e_{2}^{\prime}\right),{ }^{16} 358\left(a_{1}^{\prime}\right),{ }^{16} 421(\times 2)$ $\left(e_{1}^{\prime}\right),{ }^{13}$ and $435\left(a_{1}^{\prime}\right) \cdot{ }^{16}$

TABLE II. Total energies (in hartree) and binding energies (in $\mathrm{kJ} \mathrm{mol}^{-1}$ ) for the $\mathrm{Si}$ atom and $\mathrm{Si}_{8}$ cluster computed at the B3LYP/6-31+G*, G2(MP2), and G2 levels of theory.

\begin{tabular}{|c|c|c|c|c|c|c|}
\hline \multirow[b]{2}{*}{ Species } & \multicolumn{3}{|c|}{ Total energy } & \multicolumn{3}{|c|}{ Binding energy ${ }^{a}$} \\
\hline & B3LYP & G2(MP2) & $\mathrm{G} 2$ & B3LYP & G2(MP2) & G2 \\
\hline $\mathrm{Si}\left[{ }^{3} P\right]$ & -289.3728612 & -288.9300142 & -288.9332428 & & & \\
\hline $\mathrm{Si}_{8}\left[C_{2 h}\left({ }^{1} A_{g}\right)\right]$ & -2315.8726606 & -2312.4642051 & -2312.4847864 & $\begin{array}{c}2307 \\
(23.91)^{\mathrm{b}}\end{array}$ & $\begin{array}{c}2660 \\
(27.57)\end{array}$ & $\begin{array}{c}2646 \\
(27.43)\end{array}$ \\
\hline
\end{tabular}

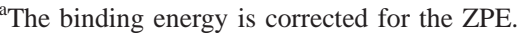

${ }^{\mathrm{b}}$ The value in parentheses is in $\mathrm{eV}$. 
TABLE III. Measured relative ion currents of the most abundant isotopes, in $A$, over the $\mathrm{Si}-\mathrm{BN}$ system, and third-law values, in $\mathrm{kJ} \mathrm{mol}^{-1}$, of the $\Delta_{a} H_{0}^{\mathrm{o}}$ of $\mathrm{Si}_{7}$ and $\mathrm{Si}_{8}$ clusters.

\begin{tabular}{|c|c|c|c|c|c|c|}
\hline \multirow[b]{2}{*}{$T(\mathrm{~K})$} & \multirow[b]{2}{*}{$\mathrm{eV}$} & \multicolumn{3}{|c|}{ Ion intensities } & \multirow{2}{*}{$\begin{array}{c}\Delta_{a} H_{0}^{\mathrm{o}} \\
\mathrm{Si}_{7}\end{array}$} & \multirow{2}{*}{$\begin{array}{c}\Delta_{a} H_{0}^{\mathrm{o}} \\
\mathrm{Si}_{8}\end{array}$} \\
\hline & & $\mathrm{Si}^{+}$ & $\mathrm{Si}_{7}^{+}$ & $\mathrm{Si}_{8}^{+}$ & & \\
\hline \multicolumn{7}{|c|}{ Series 1} \\
\hline 1763 & 18 & $2.21 E-10$ & $6.00 E-14$ & & 2403.7 & \\
\hline 1789 & 18 & $3.53 E-10$ & $8.00 E-14$ & $3.00 E-14$ & 2393.5 & 2744.3 \\
\hline 1819 & 18 & $5.15 E-10$ & $1.60 E-13$ & $7.00 E-14$ & 2402.8 & 2755.9 \\
\hline 1993 & 11 & $2.35 E-10$ & $1.00 E-13$ & & 2381.0 & \\
\hline \multicolumn{7}{|c|}{ Series 2} \\
\hline 1970 & 13 & $3.40 E-10$ & $4.80 E-14$ & $2.90 E-14$ & 2376.9 & 2728.5 \\
\hline 1985 & 13 & $4.25 E-10$ & $6.00 E-14$ & $4.30 E-14$ & 2372.3 & 2725.6 \\
\hline 1970 & 18 & $7.14 E-10$ & $2.00 E-13$ & $6.10 E-14$ & 2397.1 & 2739.0 \\
\hline \multirow[t]{2}{*}{1985} & 18 & $1.08 E-09$ & $2.50 E-13$ & $1.50 E-13$ & 2370.4 & 2719.1 \\
\hline & & & & & $2387.2 \pm 13.6^{\mathrm{a}}$ & $2735.4 \pm 13.6$ \\
\hline
\end{tabular}

${ }^{a}$ The error terms are standard deviations.

For $\mathrm{Si}_{8}$ the structure and molecular parameters computed by the levels of theory stipulated in the G2 method were used as listed in Table I.

Table IV lists the thermal functions calculated for $\mathrm{Si}_{7}$ and $\mathrm{Si}_{8}$.

\section{B. Atomization energies and enthalpies of formation}

The enthalpy of the atomization reaction,

$$
\mathrm{Si}_{n}(g)=n \operatorname{Si}(g) \quad n=7 \text { or } 8
$$

was evaluated according to the third-law method, using the relation $\Delta_{r} H_{0}^{\mathrm{o}}=-R T \ln K_{p}-T \Delta\left[\left(G_{T}^{\mathrm{o}}-H_{0}^{\mathrm{o}}\right) / T\right]$. A secondlaw evaluation was not reliable due to the limited number of data. The results are listed in Table III.

Averaging the measured atomization enthalpies, in $\mathrm{kJ} \mathrm{mol}^{-1}$, for $\mathrm{Si}_{7}$ and $\mathrm{Si}_{8}$ yields $\Delta_{a} H_{0}^{\mathrm{o}}\left(\mathrm{Si}_{7}, g\right)=2387.2$ \pm 13.6 and $\Delta_{a} H_{0}^{\mathrm{o}}\left(\mathrm{Si}_{8}, g\right)=2735.4 \pm 13.6$, where the errors are standard deviations. The recommended value for the atomization energy of $\mathrm{Si}_{8}$ is $(2735 \pm 65) \mathrm{kJ} \mathrm{mol}^{-1}$. Here the uncertainty is the overall error, calculated as in Schmude et al. $^{59}$

We have also used the data by Chatillon ${ }^{56}$ to carry out a third-law evaluation for the atomization reaction of $\mathrm{Si}_{7}$. Chatillon ${ }^{56}$ reported seven measurements in the temperature range 1910-2140 $\mathrm{K}$, and derived a second-law value of $\Delta_{a} H_{2015}^{\mathrm{o}}\left(\mathrm{Si}_{7}, g\right)=(2377 \pm 83) \mathrm{kJ} \mathrm{mol}^{-1}$ for reaction (1). We determined the ion intensities of $\mathrm{Si}^{+}$and $\mathrm{Si}_{7}^{+}$from his plots of $\log \left(I^{+} T\right)$ versus $1 / T$. The pressure constant $k(\mathrm{Si})$ was ob-

TABLE IV. The Gibbs energy functions, $\left(G_{T}^{\mathrm{o}}-H_{0}^{\mathrm{o}}\right) / T\left(\mathrm{GEF}_{0}\right)$, in $\mathrm{J} \mathrm{K}^{-1} \mathrm{~mol}^{-1}$, and the heat content functions, $H_{T}^{\mathrm{o}}-H_{0}^{\mathrm{o}}\left(\mathrm{HCF}_{0}\right)$, in $\mathrm{kJ} \mathrm{mol}^{-1}$, for $\mathrm{Si}_{7}$ and $\mathrm{Si}_{8}$ clusters. The reference pressure is 1 bar.

\begin{tabular}{cccccccc}
\hline \hline & \multicolumn{7}{c}{ Temperature (K) } \\
\cline { 2 - 8 } Species & & 298.15 & 1400 & 1600 & 1800 & 2000 & 2200 \\
\hline $\mathrm{Si}_{7}$ & $-\mathrm{GEF}_{0}$ & 282.8 & 465.4 & 484.1 & 500.9 & 516.0 & 529.9 \\
& $\mathrm{HCF}_{0}$ & 26.38 & 195.0 & 226.4 & 257.8 & 289.3 & 320.8 \\
$\mathrm{Si}_{8}$ & $-\mathrm{GEF}_{0}$ & 325.4 & 543.6 & 565.6 & 585.2 & 602.9 & 619.1 \\
& $\mathrm{HCF}_{0}$ & 32.61 & 228.9 & 265.7 & 301.7 & 338.2 & 374.7 \\
\hline \hline
\end{tabular}

tained by comparing the ion intensities of $\mathrm{Si}^{+}$with the partial pressures of $\mathrm{Si}$ from Gurvich et al. ${ }^{71}$ assuming unit activity of the liquid silicon. The small decrease in the activity of the silicon due to solution of some carbon in the liquid silicon at the high temperatures, observed by Chatillon, ${ }^{56}$ was deemed to be within the error limits of the ion current measurements. The pressure constant for $\mathrm{Si}_{7}$ was evaluated using the same procedure above described in the experimental section. Employing the Gibbs free energy functions for $\mathrm{Si}_{7}$ and $\mathrm{Si}$ used in this investigation, an average third-law $\Delta_{a} H_{0}^{\mathrm{o}}$ for $\mathrm{Si}_{7}$ was calculated as $(2373.8 \pm 7.9) \mathrm{kJ} \mathrm{mol}^{-1}$, where the error is the standard deviation. Chatillon's corresponding second-law value, when corrected to $0 \mathrm{~K}$ reference temperature, becomes $(2359 \pm 83) \mathrm{kJ} \mathrm{mol}^{-1}$, in agreement with the third-law value. Similarly we have evaluated the experimental relative ion intensities of $\mathrm{Si}$ and $\mathrm{Si}_{7}$ from Honig $^{8}$ at $1660 \mathrm{~K}$ by the third-law method, yielding a value of $\Delta_{a} H_{0}^{\mathrm{o}}\left(\mathrm{Si}_{7}, g\right)=(2438 \pm 70) \mathrm{kJ} \mathrm{mol}^{-1}$. This value agrees within the error limits with that from the present investigation, but it has not been taken into account in our selection of the final value for $\Delta_{a} H_{0}^{\mathrm{o}}\left(\mathrm{Si}_{7}, g\right)$ because it was obtained under Langmuir conditions of vaporization.

The selected value for the atomization energy of $\mathrm{Si}_{7}$ was obtained as the weighted average of the experimental thirdlaw values achieved in this investigation and from Chatillon's analyzed data. The weight for each value was taken as the square root of the number of data points. The resulting $\Delta_{a} H_{0}^{\mathrm{o}}\left(\mathrm{Si}_{7}, g\right)$ is $(2380.7 \pm 36) \mathrm{kJ} \mathrm{mol}^{-1}$. Here the uncertainty is the overall uncertainty calculated from the estimated uncertainties as reported in Ref. 59.

The enthalpies of formation of $\mathrm{Si}_{7}$ and $\mathrm{Si}_{8}$ have been obtained from the present atomization energies and the en-

TABLE V. Thermodynamic properties for $\mathrm{Si}_{7}$ and $\mathrm{Si}_{8}$ clusters. All values are in $\mathrm{kJ} \mathrm{mol}^{-1}$

\begin{tabular}{ccccc}
\hline \hline Species & $\Delta_{a} H_{0}^{\mathrm{o}}$ & $\Delta_{a} H_{298.15}^{\mathrm{o}}$ & $\Delta_{f} H_{0}^{\mathrm{o}}$ & $\Delta_{f} H_{298.15}^{\mathrm{o}}$ \\
\hline $\mathrm{Si}_{7}$ & $2381 \pm 36$ & $2407 \pm 36$ & $739 \pm 36$ & $743 \pm 36$ \\
$\mathrm{Si}_{8}$ & $2735 \pm 65$ & $2763 \pm 65$ & $831 \pm 65$ & $837 \pm 65$ \\
\hline \hline
\end{tabular}


thalpy of sublimation for silicon from Gurvich et al.,$^{71} \mathrm{em}-$ ploying the relation $\Delta_{f} H_{T}^{\mathrm{o}}\left(\mathrm{Si}_{n}\right)=n \Delta_{f} H_{T}^{\mathrm{o}}(\mathrm{Si})-\Delta_{a} H_{T}^{\mathrm{o}}\left(\mathrm{Si}_{n}\right)$, where $T$ is 0 or $298.15 \mathrm{~K}$. The thermodynamic properties for $\mathrm{Si}_{7}$ and $\mathrm{Si}_{8}$ clusters have been summarized in Table V.

With the standard enthalpy of formation of atomic silicon, $\quad \Delta_{f} H_{298.15}^{\mathrm{o}}(\mathrm{Si}, g)=(455.6 \pm 4.2) \mathrm{kJ} \mathrm{mol}^{-1}, \quad$ from Hultgren et al. ${ }^{, 4}$ the standard enthalpies of formation, $\Delta_{f} H_{298.15}^{\mathrm{o}}\left(\mathrm{Si}_{n}, g\right)$, for the $\mathrm{Si}_{7}$ and $\mathrm{Si}_{8}$ clusters, in $\mathrm{kJ} \mathrm{mol}^{-1}$, become $783 \pm 35$ and $887 \pm 65$, respectively. With the standard enthalpy of formation of silicon, $\Delta_{f} H_{298.15}^{\mathrm{o}}(\mathrm{Si}, g)$ $=(445.3 \pm 5.0) \mathrm{kJ} \mathrm{mol}^{-1}$, from Rocabois et al. ${ }^{75}$ the values for $\Delta_{f} H_{298.15}^{\mathrm{o}}\left(\mathrm{Si}_{n}, g\right)$, in $\mathrm{kJ} \mathrm{mol}^{-1}$, result in $711 \pm 35$ for $\mathrm{Si}_{7}$ and $804 \pm 65$ for $\mathrm{Si}_{8}$. Evidently, the choice of the enthalpy of sublimation of silicon makes a significant difference on the $\Delta_{f} H_{298.15}^{\mathrm{o}}\left(\mathrm{Si}_{n}, g\right)$ values.

It is worth comparing the atomization enthalpies of $\mathrm{Si}_{n}(n=2-6)$ obtained from the enthalpies of formation of $\mathrm{Si}_{n}(n=2-6)$ determined by Rocabois et al. ${ }^{57}$ and $\Delta_{f} H_{0}^{\mathrm{o}}(\mathrm{Si}, g)$ from Gurvich et al. ${ }^{71}$ with the values obtained in our laboratory. $\Delta_{a} H_{0}^{\mathrm{o}}\left(\mathrm{Si}_{n}, g\right)$ values, in $\mathrm{kJ} \mathrm{mol}^{-1}$, from our laboratory and from Rocabois et al. ${ }^{57}$ respectively, are $\mathrm{Si}_{2}$, $319.0 \pm 7.0$ (Ref. 58) and 311.2 $\pm 9.4 .{ }^{57} \mathrm{Si}_{3}, 705 \pm 16$ (Ref. 58) and 696.8 $\pm 7.95^{57} \mathrm{Si}_{4}, 1151 \pm 22$ (Ref. 58) and $1133.4 \pm 8.3 ;{ }^{57} \mathrm{Si}_{5}, 1559 \pm 24$ (Ref. 60) and $1548.3 \pm 10.3 ;{ }^{57}$ $\mathrm{Si}_{6}, 1981 \pm 32$ (Ref. 61) and 1949.8 $\pm 18.3 .^{57}$ The values from these independent studies agree within the given error limits.

From the $\Delta_{a} H_{0}^{\mathrm{o}}$ values, the fragmentation energies or incremental dissociation energies, $\Delta_{a} H_{0}^{\mathrm{o}}\left(\mathrm{Si}_{n}\right)$ $-\Delta_{a} H_{0}^{\mathrm{o}}\left(\mathrm{Si}_{n-1}\right)$, can be derived. Large values of fragmentation energies, defined as the minimum energy required removing an atom from the cluster, imply a higher stability than neighboring clusters containing one more or one less atom. The obtained fragmentation energies are, in $\mathrm{eV}, 3.86$ and 4.18 for $\mathrm{Si}_{7}$ and $\mathrm{Si}_{8}$, respectively. In arriving at the fragmentation energy of $\mathrm{Si}_{7}$ the value for the atomization energy of $\mathrm{Si}_{6}, \Delta_{a} H_{0}^{\mathrm{o}}\left(\mathrm{Si}_{6}, g\right)=(20.53 \pm 0.06)$ (Ref. 61) eV was used.

These values together with the mass spectrometric incremental dissociation energies of the silicon clusters containing from 3 to 6 atoms can be compared with the fragmentation energy values of the group 14 atomic clusters. The $\Delta_{a} H_{0}^{\mathrm{o}}$ values for $\mathrm{C}_{n}, \mathrm{Ge}_{n}$, and $\mathrm{Sn}_{n}$ clusters are taken from previous investigations: for $\mathrm{C}_{n}(n=2-7)$ from Gingerich et al. ${ }^{62}$ for $\mathrm{Si}_{n}(n=2-5)$ from Ran et al. ${ }^{60}$ and for $\mathrm{Si}_{6}$ from Gingerich et al. $;{ }^{61}$ for $\mathrm{Ge}_{n}(n=2-8)$ from Gingerich et al. ${ }^{63,76}$ for

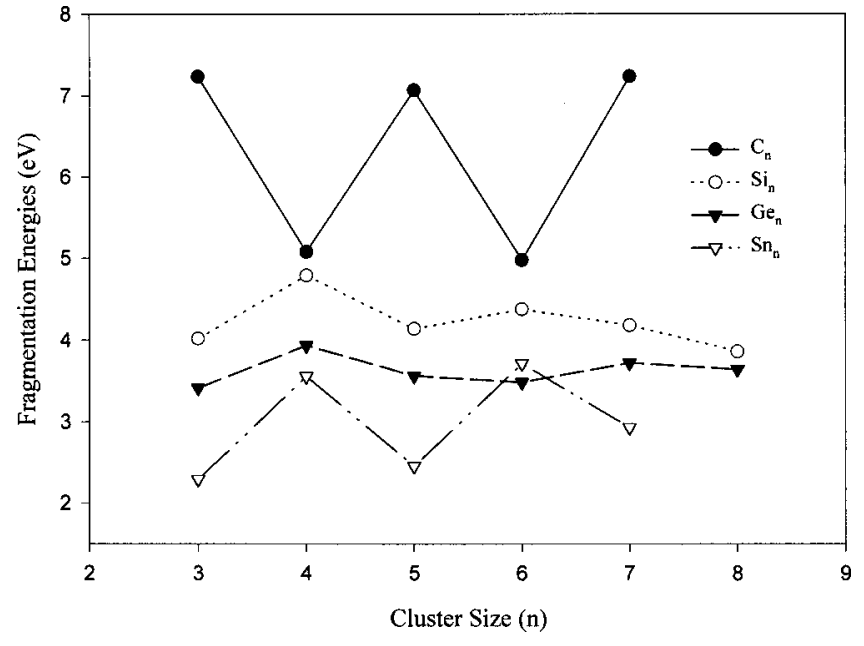

FIG. 2. Fragmentation energies, $\Delta_{a} H_{0}^{\mathrm{o}}\left(\mathrm{X}_{n}\right)-\Delta_{a} H_{0}^{\mathrm{o}}\left(\mathrm{X}_{n-1}\right)$, of the group 14 atomic clusters vs the cluster size $(n)$.

$\mathrm{Sn}_{n}(n=2-3)$ from Gingerich et al.; ${ }^{77}$ and for $\operatorname{Sn}_{n}(n$ $=4-7$ ) from Meloni et al. ${ }^{64}$ In Fig. 2 the fragmentation energies of group 14 atomic clusters are plotted versus the number of atoms. The trend of the incremental dissociation energies is similar for $\mathrm{Si}, \mathrm{Ge}$, and $\mathrm{Sn}$ clusters, showing a higher stability for the even-numbered atom clusters, especially those with four atoms. This behavior is different from that for the carbon clusters, where the enhanced stability of odd-numbered carbon clusters is due to completely filled $\pi$ molecular orbitals. Small carbon clusters exhibit chain or ring structures, while silicon, germanium, and tin clusters with five to eight atoms show more complex polyhedral structures.

It is also interesting to calculate the binding energies, or atomization enthalpies, of silicon clusters anions for the reaction $\mathrm{Si}_{n}^{-}(g)=(n-1) \mathrm{Si}(g)+\mathrm{Si}^{-}(g)$, using the experimental values of their electron affinities (EA) and the values for the atomization energies of the neutral clusters from our laboratory. The results, in $\mathrm{eV}$, are 8.21 for $\mathrm{Si}_{3}^{-}, 12.67$ for $\mathrm{Si}_{4}^{-}, 17.36$ for $\mathrm{Si}_{5}^{-}, 20.84$ for $\mathrm{Si}_{6}^{-}, 25.13$ for $\mathrm{Si}_{7}^{-}$, and 29.05 for $\mathrm{Si}_{8}^{-}$. The relation used is $\Delta_{a} H_{0}^{\mathrm{o}}\left(\mathrm{Si}_{n}^{-}\right)=\Delta_{a} H_{0}^{\mathrm{o}}\left(\mathrm{Si}_{n}\right)$ $-\mathrm{EA}(\mathrm{Si})+\mathrm{EA}\left(\mathrm{Si}_{n}\right)$. The experimental electron affinities (in $\mathrm{eV})$ were taken from Scheer et $_{\text {al. }}{ }^{78}$ for the atomic silicon (1.389521 \pm 0.000020$)$, from Xu et al. ${ }^{15}$ for $\mathrm{Si}_{3}$ (2.29 $\pm 0.02), \mathrm{Si}_{4}(2.13 \pm 0.01), \mathrm{Si}_{5}(2.59 \pm 0.02)$, and $\mathrm{Si}_{7}(1.85$ $\pm 0.02)$, and from Kishi et al. ${ }^{67}$ for $\mathrm{Si}_{6}(2.00 \pm 0.03)$ and $\mathrm{Si}_{8}$

TABLE VI. A comparison of experimental atomization energies, in $\mathrm{eV}$, for $\mathrm{Si}_{7}$ and $\mathrm{Si}_{8}$ clusters with theoretical values.

\begin{tabular}{|c|c|c|c|c|c|c|c|c|c|c|c|}
\hline & Experiment & & MP4 & & PW/VWN & PWB & & & INTB $^{g}$ & & \\
\hline Species & This investigation & $\mathrm{MP}^{\mathrm{a}}$ & Corr. $^{\mathrm{a}}$ & GVB-ECP ${ }^{b}$ & $\mathrm{DF}^{\mathrm{c}}$ & $\mathrm{DF}^{\mathrm{d}}$ & $\mathrm{TB}^{\mathrm{e}}$ & NTB $^{f}$ & (Set 1) & TBMD $^{\mathrm{h}}$ & FBTB $^{i}$ \\
\hline $\mathrm{Si}_{7}$ & $24.67 \pm 0.37$ & 22.16 & 26.60 & 13.86 & 24.91 & 24.89 & 24.50 & 26.95 & 26.11 & 33.33 & 26.41 \\
\hline $\mathrm{Si}_{8}$ & $28.35 \pm 0.67$ & 24.31 & 29.20 & 14.72 & 28.01 & 27.93 & 28.00 & 28.96 & 29.36 & 37.33 & 30.52 \\
\hline
\end{tabular}

${ }^{\text {aReference } 19 .}$

${ }^{\mathrm{b}}$ Reference 21.

${ }^{\mathrm{c}}$ Reference 23.

${ }^{\mathrm{d}}$ Reference 50.

e Reference 27.
${ }^{\mathrm{f}}$ Reference 28 .

${ }^{g}$ Reference 29.

${ }^{\mathrm{h}}$ Reference 31.

${ }^{\mathrm{i}}$ Reference 32. 
TABLE VII. A comparison of computed atomization energies, in $\mathrm{eV}$, for $\mathrm{Si}_{7}$ and $\mathrm{Si}_{8}$.

\begin{tabular}{|c|c|c|c|c|c|c|c|c|}
\hline Species & LSD-MD-xcg & LDA-BLYP $^{b}$ & $\mathrm{IPF}^{\mathrm{c}}$ & QMC-LDA $^{\mathrm{d}}$ & $\mathrm{DMC}^{\mathrm{d}}$ & B3LYP & $\begin{array}{c}\text { G2 } \\
\text { (MP2) }\end{array}$ & $\mathrm{G} 2^{\mathrm{e}}$ \\
\hline $\mathrm{Si}_{7}$ & 27.46 & 24.78 & 23.84 & 28.98 & 24.01 & $\cdots$ & $24.95^{\mathrm{f}}$ & $\cdots$ \\
\hline $\mathrm{Si}_{8}$ & 30.89 & $\ldots$ & 27.98 & $\cdots$ & $\cdots$ & 23.91 & $27.57^{\mathrm{e}}$ & 27.43 \\
\hline $\begin{array}{l}{ }^{2} \text { Referen } \\
\text { 'Referen } \\
{ }^{\circ} \text { Referen }\end{array}$ & $\begin{array}{l}37 \\
40 \\
46\end{array}$ & & & $\begin{array}{l}{ }^{\mathrm{d}} \text { Referenc } \\
{ }^{\mathrm{e}} \text { This inve } \\
{ }^{\mathrm{f}} \text { Referenc }\end{array}$ & $\begin{array}{l}48 . \\
\text { tigation. } \\
69 .\end{array}$ & & & \\
\hline
\end{tabular}

(2.09 \pm 0.15$)$. Xu et al. ${ }^{15}$ did not measure the EA's of $\mathrm{Si}_{6}$ and $\mathrm{Si}_{8}$, whereas Kishi et al. ${ }^{67}$ determined the EA values for $\mathrm{Si}_{n}(n=4-11)$.

\section{Comparison of experimental and theoretical atomization energies}

During the years many theoretical methods have been improved in predicting binding or atomization energies of small group 14 clusters, especially those of carbon and silicon, with chemical accuracy ${ }^{69}$ One of the most reliable theoretical methods for such small clusters is the G2 theory.

In Tables VI and VII we compare the experimental atomization energies of $\mathrm{Si}_{7}$ and $\mathrm{Si}_{8}$ clusters obtained in the present investigation with the corresponding theoretical values.

Raghavachari and Rohlfing ${ }^{19}$ performed fourth order Møller-Plesset (MP4) calculations on $\mathrm{Si}_{7}$. The corrected MP4 binding energies, obtained by multiplying the MP4 values by an empirical scale factor of 1.2, due to their underestimation of the binding energies of $\mathrm{Si}_{2}$ and $\mathrm{Si}_{3}$, are slightly higher than our experimental atomization energies. Patterson and Messmer $^{21}$ carried out ab initio generalized-valencebond (GVB) calculations with an effective core-potential $(\mathrm{ECP})$. Although they obtained the optimized ground state geometries for $\mathrm{Si}_{7}$ and $\mathrm{Si}_{8}$ clusters in agreement with the accepted structures, their binding energies values are considerably lower when compared with the other theoretical results in the literature. Fournier et al. ${ }^{23}$ reported the equilibrium geometry, vibrational frequencies, and atomization enthalpies for the ground state obtained with the linear combination of Gaussian-type atomic orbitals-density functional (LCGO-DF) method, using the local spin density (LSD) potential of Vosko, Wilk, and Nusair (VWN), and PerdewWang (PW) gradient corrected functional. Shvartsburg et al. ${ }^{50}$ in similar calculations, used a Perdew-Wang-Becke (PWB) gradient corrected functional. The $\Delta_{a} H_{0}^{\mathrm{o}}$ values from both such computations are in very good agreement with our experimental results. Within the tight-binding (TB) approximation, the only values comparable with the binding energies obtained in this investigation are those calculated by Tománek and Schlüter, ${ }^{27}$ but the $\mathrm{Si}_{7}$ geometry they calculated is a capped octahedron. The other TB variants, nonorthogonal tight-binding (NTB), ${ }^{28}$ improved nonorthogonal tight-binding (INTB), ${ }^{29}$ tight-binding molecular dynamics (TBMD) ${ }^{31}$ fractional bond tight-binding (FBTB), ${ }^{32}$ and the quantum Monte Carlo (QMC) method with the local density approximation (LDA) (Ref. 48) give higher values than the experimental results. With the FBTB (Ref. 32) model the lowest energy $\mathrm{Si}_{8}$ structure is a distorted bicapped octahe- dron, which is capped on adjacent faces, whereas ab initio calculations indicate that the most favorable arrangement corresponds to capping two opposite faces. Wei et $_{\text {al. }}{ }^{37}$ calculated $\Delta_{a} H_{0}^{\mathrm{o}}$ values higher than our experimental values performing LSD-MD calculations with the exchangecorrelation (xcg) gradient correction. Eguchi et al. ${ }^{40}$ obtained almost the same as the experimental value for $\Delta_{a} H_{0}^{\mathrm{o}}\left(\mathrm{Si}_{7}, g\right)$, using the LDA and the Becke-Lee-Yang-Parr (BLYP) functional. Bolding and Anderson ${ }^{46}$ using an interatomic potential functional (IPF) determined $\Delta_{a} H_{0}^{\mathrm{o}}\left(\mathrm{Si}_{7}, g\right)$ and $\Delta_{a} H_{0}^{\mathrm{o}}\left(\mathrm{Si}_{8}, g\right)$ slightly lower than the experimental values. Grossman and Mitás ${ }^{48}$ using diffusion Monte Carlo (DMC) method showed that the binding energy for $\mathrm{Si}_{7}$ calculated with this method agrees within about $3 \%$ with experiment. The G2 values for $\mathrm{Si}_{7}$ (Ref. 69) and $\mathrm{Si}_{8}$ (present investigation) are in good agreement with the experimental values.

\section{ACKNOWLEDGMENTS}

The authors are grateful to the Robert A. Welch Foundation for financial support of this work. One of the authors (G.M.) wishes to thank the Laboratory of Molecular Simulation in the Chemistry Department at Texas A\&M University for helpful discussions and contributions.

${ }^{1}$ Physics and Chemistry of Finite Systems: From Clusters to Crystals, edited by P. Jena, S. N. Khanna, and B. K. Rao (Kluwer Academic, Dordrecht, The Netherlands, 1992), Vols. 1 and 2.

${ }^{2}$ R. Neuendorf, R. E. Palmer, and R. Smith, Appl. Phys. Lett. 77, 3003 (2000).

${ }^{3}$ R. Neuendorf, R. E. Palmer, and R. Smith, Chem. Phys. Lett. 333, 304 (2001).

${ }^{4}$ T. I. Cox, A. J. Simons, A. Loni, P. D. J. Calcott, L. T. Canham, M. J. Uren, and K. J. Nash, J. Appl. Phys. 86, 2764 (1999).

${ }^{5}$ L. T. Canham, Appl. Phys. Lett. 57, 1046 (1990).

${ }^{6}$ O. Bisi, S. Ossicini, and L. Pavesi, Surf. Sci. Rep. 38, 1 (2000).

${ }^{7}$ A. G. Cullis and L. T. Canham, Nature (London) 353, 335 (1991).

${ }^{8}$ R. E. Honig, J. Chem. Phys. 22, 1610 (1954).

${ }^{9}$ T. P. Martin and H. Schaber, J. Chem. Phys. 83, 855 (1985).

${ }^{10}$ L. A. Bloomfield, R. R. Freeman, and W. L. Brown, Phys. Rev. Lett. 54, 2246 (1985)

${ }^{11}$ L. A. Bloomfield, M. E. Geusic, R. R. Freeman, and W. L. Brown, Chem. Phys. Lett. 121, 33 (1985).

${ }^{12}$ E. C. Honea, A. Ogura, C. A. Murray, K. Raghavachari, W. O. Sprenger, M. F. Jarrold, and W. L. Brown, Nature (London) 366, 42 (1993).

${ }^{13} \mathrm{~S}$. Li, R. J. Van Zee, W. Weltner, Jr., and K. Raghavachari, Chem. Phys. Lett. 243, 275 (1995).

${ }^{14}$ G. Schulze Icking-Konert, H. Handschuh, P. S. Bechthold, G. Ganteför, B. Kessler, and W. Eberhardt, Surf. Rev. Lett. 3, 483 (1996).

${ }^{15}$ C. Xu, T. R. Taylor, G. R. Burton, and D. M. Neumark, J. Chem. Phys. 108, 1395 (1998).

${ }^{16}$ E. C. Honea, A. Ogura, D. R. Peale, C. Félix, C. A. Murray, K. Raghavachari, W. O. Sprenger, M. F. Jarrold, and W. L. Brown, J. Chem. Phys. 110, 12161 (1999).

${ }^{17}$ K. Raghavachari and V. Logovinsky, Phys. Rev. Lett. 55, 2853 (1985). 
${ }^{18}$ K. Raghavachari, J. Chem. Phys. 84, 5672 (1986).

${ }^{19}$ K. Raghavachari and C. M. Rohlfing, J. Chem. Phys. 89, 2219 (1988).

${ }^{20}$ C. M. Rohlfing and K. Raghavachari, Chem. Phys. Lett. 167, 559 (1990).

${ }^{21}$ C. H. Patterson and R. P. Messmer, Phys. Rev. B 42, 7530 (1990).

${ }^{22}$ L. A. Curtiss, P. W. Deutsch, and K. Raghavachari, J. Chem. Phys. 96, 6868 (1992).

${ }^{23}$ R. Fournier, S. B. Sinnott, and A. E. DePristo, J. Chem. Phys. 97, 4149 (1992).

${ }^{24}$ K. Jackson, M. R. Pederson, D. Porezag, Z. Hajnal, and T. Frauenheim, Phys. Rev. B 55, 2549 (1997).

${ }^{25}$ B. Hartke, Theor. Chem. Acc. 99, 241 (1998).

${ }^{26}$ D. Tománek and M. A. Schlüter, Phys. Rev. Lett. 56, 1055 (1986).

${ }^{27}$ D. Tománek and M. A. Schlüter, Phys. Rev. B 36, 1208 (1987).

${ }^{28}$ M. Menon and K. R. Subbaswamy, Phys. Rev. B 47, 12754 (1993).

${ }^{29}$ P. Ordejón, D. Lebedenko, and M. Menon, Phys. Rev. B 50, 5645 (1994).

${ }^{30}$ A. Sieck, D. Porezag, T. Frauenheim, M. R. Pederson, and K. Jackson, Phys. Rev. A 56, 4890 (1997).

${ }^{31}$ W. Fa and C. L. Luo, Acta Metall. Sin. 12, 534 (1999).

${ }^{32}$ Y. Luo, J. Zhao, and G. Wang, Phys. Rev. B 60, 10703 (1999).

${ }^{33}$ C. Jo and K. Lee, Phys. Lett. A 263, 376 (1999).

${ }^{34}$ P. Ballone, W. Andreoni, R. Car, and M. Parrinello, Phys. Rev. Lett. 60, 271 (1988)

${ }^{35}$ W. Andreoni and G. Pastore, Phys. Rev. B 41, 10243 (1990).

${ }^{36}$ N. Binggeli, J. L. Martins, and J. R. Chelikowsky, Phys. Rev. Lett. 68, 2956 (1992)

${ }^{37}$ S. Wei, R. N. Barnett, and U. Landman, Phys. Rev. B 55, 7935 (1997).

${ }^{38}$ D. W. Dean and J. R. Chelikowsky, Theor. Chem. Acc. 99, 18 (1998).

${ }^{39}$ K. Zickfeld, M. E. Garcia, and K. H. Bennemann, Phys. Rev. B 59, 13422 (1999).

${ }^{40}$ H. Eguchi, K. Tsumuraya, T. Nagano, and S. Kihara, Mater. Trans., JIM 40, 1198 (1999)

${ }^{41}$ B.-X. Li, M. Qiu, and P.-L. Cao, Phys. Lett. A 256, 386 (1999).

${ }^{42}$ B.-X. Li, P.-L. Cao, and M. Jiang, Phys. Status Solidi B 218, 399 (2000).

${ }^{43}$ B. K. Panda, S. Mukherjee, and S. N. Behera, Phys. Rev. B 63, 045404 (2001).

${ }^{44}$ J. A. Niesse and H. R. Mayne, Chem. Phys. Lett. 261, 576 (1996).

${ }^{45}$ M. Iwamatsu, J. Chem. Phys. 112, 10976 (2000).

${ }^{46}$ B. C. Bolding and H. C. Andersen, Phys. Rev. B 41, 10568 (1990).

${ }^{47}$ N. Govind, J.-L. Mozos, and H. Guo, Phys. Rev. B 51, 7101 (1995).

${ }^{48}$ J. C. Grossman and L. Mitáš, Phys. Rev. Lett. 74, 1323 (1995).

${ }^{49}$ M. F. Jarrold and V. A. Constant, Phys. Rev. Lett. 67, 2994 (1991).

${ }^{50}$ A. A. Shvartsburg, B. Liu, M. F. Jarrold, and K.-M. Ho, J. Chem. Phys. 112, 4517 (2000).

${ }^{51}$ D. J. Trevor, D. M. Cox, K. C. Reichmann, R. O. Brickman, and A. Kaldor, J. Phys. Chem. 91, 2598 (1987).

${ }^{52}$ K. Fuke, K. Tsukamoto, F. Misaizu, and M. Sanekata, J. Chem. Phys. 99, 7807 (1993)

${ }^{53}$ O. Cheshnovsky, S. H. Yang, C. L. Pettiette, M. J. Craycraft, Y. Liu, and R. E. Smalley, Chem. Phys. Lett. 138, 119 (1987).

${ }^{54}$ C. C. Arnold and D. Neumark, J. Chem. Phys. 99, 3353 (1993).
${ }^{55}$ T. Bachels and R. Schäfer, Chem. Phys. Lett. 324, 365 (2000).

${ }^{56}$ M. M. C. Chatillon, Ph.D. thesis, L'Universite Scientifique et Medicale De Grenoble, Grenoble, France, 1975.

${ }^{57}$ P. Rocabois, C. Chatillon, C. Bernard, and F. Genet, High Temp.-High Press. 27/28, 25 (1996)

${ }^{58}$ R. W. Schmude, Jr., Q. Ran, K. A. Gingerich, and J. E. Kingcade, Jr., J. Chem. Phys. 102, 2574 (1995).

${ }^{59}$ R. W. Schmude, Jr., Q. Ran, and K. A. Gingerich, J. Chem. Phys. 99, 7998 (1993).

${ }^{60}$ Q. Ran, R. W. Schmude, Jr., M. Miller, and K. A. Gingerich, Chem. Phys. Lett. 230, 337 (1994).

${ }^{61}$ K. A. Gingerich, Q. Ran, and R. W. Schmude, Jr., Chem. Phys. Lett. 256, 274 (1996).

${ }^{62}$ K. A. Gingerich, H. C. Finkbeiner, and R. W. Schmude, Jr., J. Am. Chem. Soc. 116, 3884 (1994).

${ }^{63}$ K. A. Gingerich, R. W. Schmude, Jr., M. Sai Baba, and G. Meloni, J. Chem. Phys. 112, 7443 (2000).

${ }^{64}$ G. Meloni, R. W. Schmude, Jr., J. E. Kingcade, Jr., and K. A. Gingerich, J. Chem. Phys. 113, 1852 (2000).

${ }^{65}$ K. A. Gingerich, D. L. Cocke, and F. Miller, J. Chem. Phys. 64, 4027 (1976).

${ }^{66}$ R. W. Schmude, Jr., Ph.D. thesis, Texas A\&M University, College Station, TX, 1994.

${ }^{67}$ R. Kishi, H. Kawamata, Y. Negishi, S. Iwata, A. Nakajima, and K. Kaya, J. Chem. Phys. 107, 10029 (1997).

${ }^{68}$ M. J. Frish, G. W. Trucks, H. B. Schlegel et al. Gaussian 98, Revision A.6 (Gaussian, Inc., Pittsburgh, 1998).

${ }^{69} \mathrm{~K}$. Raghavachari and L. A. Curtiss, in Quantum Mechanical Electronic Structure Calculations with Chemical Accuracy, edited by S. R. Langhoff (Kluwer Academic, The Netherlands, 1995), p. 173.

${ }^{70} \mathrm{~K}$. A. Gingerich, in Current Topics in Materials Science, edited by E. Kaldis (North-Holland, Amsterdam, 1980), Vol. 6, p. 345.

${ }^{71}$ Thermodynamic Properties of Individual Substances, edited by L. V. Gurvich, I. V. Veyts, and C. B. Alcock (Hemisphere, New York, 1991), Vol. 2.

${ }^{72}$ D. R. Stull and H. Prophet, in Characterization of High Temperature Vapors, edited by J. L. Margrave (Wiley-Interscience, New York, 1971), p. 359.

${ }^{73} \mathrm{~K}$. Raghavachari (private communication).

${ }^{74}$ R. Hultgren, P. D. Desai, D. T. Hawkins, M. Gleiser, K. K. Kelly, and D. D. Wagman, Selected Values of the Thermodynamic Properties of the Elements (American Society for Metals, Metals Park, OH, 1973).

${ }^{75}$ P. Rocabois, C. Chatillon, and C. Bernard, High Temp.-High Press. 27/28, 3 (1996).

${ }^{76}$ K. A. Gingerich, M. Sai Baba, R. W. Schmude, Jr., and J. E. Kingcade, Jr., Chem. Phys. 262, 65 (2000).

${ }^{77}$ K. A. Gingerich, E. A. Ramakrishnan, and J. E. Kingcade, Jr., High. Temp. Sci. 21, 1 (1986).

${ }^{78}$ M. Scheer, R. C. Bilodeau, C. A. Brodie, and H. K. Haugen, Phys. Rev. A 58, 2844 (1998) 
Journal of Chemical Physics is copyrighted by AIP Publishing LLC (AIP). Reuse of AIP content is subject to the terms at: http://scitation.aip.org/termsconditions. For more information, see http://publishing.aip.org/authors/rights-and-permissions. 